\title{
Pragmática Transcendental e Ética do Discurso:
}

\section{Tópicos sobre a comunidade de comunicação em Karl-Otto Apel}

\section{Transcendental Pragmatics and Discourse Ethics:}

Topics about the communication community in Karl-Otto Apel

\section{Drauzio Gonzaga}

Quando se delibera sobre política, em que tudo se baseia na justiça e na temperança, os atenienses têm razão de admitir todo mundo, porque é preciso que todo mundo participe da virtude civil, sem isso não há cidade.

Protágoras, Platão

1) O pensamento filosófico predominante no Século $X X$ parece ter se caracterizado, entre outras coisas, pela ideia de uma separação intransponível entre a racionalidade da ciência positiva e uma supostamente insuperável irracionalidade das decisões valorativas por parte dos sujeitos individuais. Ainda sob a influência de Hume, entre outros iluministas, a contemporaneidade novecentista conservava a ideia de uma incompatibilidade entre a ordem descritivo-objetiva e a ordem prescritivo-valorativa, quer dizer, uma fissura natural entre sere dever-ser, juízos de realidade e juízos de valor. A sociologia de Max Weber e o decisionismo de Hans Albert, para além de suas diferenças e especificidades, podem ser também dois marcos contemporâneos deste tipo de concepção: por um lado, só os juízos verificáveis empiricamente ou as estruturas sintático-semânticas coordenadas numa cadeia lógica de proposições poderiam reivindicar e gozar do status de racionalidade, enquanto, por outro lado, os juízos normativos, ou seja, aqueles que se referem a decisões valorativas e subjetivas na vida ética, estariam para sempre relegados a um julgamento relativista e sem possibilidade de uma sustentação racional: não existiria, então, uma razão prática no fundamento das ações humanas, estas volatizariam nas contingências e nos interesses subjetivos de cada momento; a dimensão prática ou performativa da vida e da linguagem estaria, por assim dizer, numa orfandade filosófica. Acontece, no entanto, que no mundo mais recente, ainda mais do que no das décadas passadas, a racionalidade tecno-científica sobrexcedeu em muito a racionalidade político-comunicativa, converteu-se em critério dominante de avaliação da vida e da cultura, possibilitou a globalização econômica e desenvolveu um potencial destruidor do planeta em ações bélicas e envenenamento da ecoesfera. Ao mesmo tempo, desenvolveu 
promissoramente uma comunicação tecno-virtual de mesma potência e extensão mundiais: a civilização cientificista se surpreendeu no paradoxo da destruição e da comunicação, ambas em escala planetária. Em tais circunstâncias, na prosperidade ou no pauperismo do mundo globalizado, a responsabilidade ética do sujeito humano ultrapassa as fronteiras locais e nacionais, se estende ao conjunto mundial e, qualquer que seja a posição que ocupe na hierarquia da desigualdade, o obriga a responder ecumenicamente: o atrofiamento da racionalidade ético-política é periclitante e atentatório. Um princípio de universalização das ações individuais se torna necessário e urgente, abrindo a dimensão de uma razão prática capaz de sustentar ética e argumentativamente as decisões humanas: a vida não se define mais nas fronteiras da tribo ou da nação. O homem, enquanto homo sapiens, deve assumir o mais depressa possível a dianteira cultural na história contemporânea antes que ele mesmo, enquanto homo faber, acabe por converter suas virtudes tecno-científicas em vícios exterminadores de sua espécie e de seu gênero (APEL, 1996).

2) A teoria do racionalismo crítico e falibilista de Hans Albert, sob inspiração de Karl Popper, imputa uma insuficiência demonstrativa ao esquema lógico e especulativo de proposições encadeadas coerentemente na busca de uma verdade pinacular que se sustente como fundamentação última de qualquer região do saber. Quer dizer: neste esquema especulativo de pensamento, a pretensão de uma fundamentação última para qualquer verdade deveria demonstrar um princípio lógico que, por sua vez, exigiria necessariamente se sustentar num outro princípio antecedente a ele e assim retroagindo num processo de regressão ao infinito. (ALBERT, 1976, p. 26) Esse expediente demonstrativo culminaria também necessariamente na interrupção abrupta e dogmática em algum ponto regressivo da cadeia de proposições: tal estrutura de raciocínio é que teria levado a metafísica a conceber Deus como causa sui. $\mathrm{Na}$ verdade, tal raciocínio implicaria simultaneamente no que se chama trilema lógico ou trilema de Münchhausen, quer dizer, toda tentativa de demonstração de uma verdade apodítica, a partir de sentenças ordenadas numa sucessão de evidências axiomáticas, teria por destino redundar num vício filosófico que incorreria inevitavelmente ou numa regressão ao infinito, ou num círculo lógico, ou numa parada autoritária do encadeamento sentencial: em suma, o ponto de Arquimedes da verdade, tão buscado pela especulação clássica, ou jamais seria alcançado, ou necessariamente enredar-se-ia em alguma petição de princípio desqualificadora da demonstração. Essa constatação levou alguns pensadores como Albert 
não só a uma admissão da insuficiência demonstrativa e da necessidade de abandono de qualquer tentativa de fundamentação última de qualquer verdade, como levou correlativamente à admissão de que todo conhecimento é falível e revisável no tempo. Assim, todas as "verdades", não só as da especulação metafísica como as das ciências positivas deveriam ser sistematicamente submetidas a críticas e corrigidas, a cada vez. Já as decisões morais não só incorreriam nos vícios do trilema ao pretenderem uma fundamentação última, como seriam, por sua vez e por sua própria natureza, relativas, irracionais, vigendo exclusivamente na subjetividade e na vida privada, além de despojadas de qualquer possibilidade de validação racional. Por fim, a ciência positiva admitiria uma razão teórica, ainda que metodicamente falível, mas as ações ou os juízos éticos não conheceriam, por sua vez, uma razão prática.

3) Apel concorda com as críticas do racionalismo falibilista de Albert ao modelo demonstrativo da especulação clássica baseada na derivação de sentenças a partir de sentenças e que redunda inevitável e alternativamente nas três dimensões do trilema lógico (a regressão ao infinito, a petição de princípio (petitio principii) ou a interrupção dogmática). No entanto, para Apel, a fundamentação última do conhecimento não tem que se basear no método de derivação proposicional da lógica silogística nem da lógica matemática na modernidade, mas sim num outro método aberto pelos estudos mais avançados da linguística contemporânea, ainda que já presente em momentos clássicos do pensamento filosófico. A visão pragmática da linguagem descortinou uma dimensão performativa das proposições e da linguagem em geral até então muito pouco considerada na comunicação humana. Apel vai compreender, principalmente a partir de Peirce, Wittgenstein e Austin, um horizonte prático dos proferimentos que coloca o sujeito linguístico entre a dimensão performativa ou realizativa de seu ato de fala e o conteúdo propriamente proposicional desse ato. A linguagem não acontece exclusivamente no plano descritivo da ciência ou no plano contemplativo da especulação abstrata: ela é pragma social, ela é ação e se inscreve no mundo da vida e da ética. Porque entenderam a linguagem exclusivamente no modelo dedutivo-sentencial, os falibilistas perderam de vista a reflexividade da fala sobre os próprios pressupostos performativos e transcendentais que dão sentido a toda comunicação, cancelando, então, toda possibilidade de fundamentação última de qualquer interação simbólica. (APEL, 1986) Na verdade, todo ato de comunicação significativo pressupõe condições transcendentais e irretrocedíveis de 
argumentação: transcendentais porque indispensáveis para o sentido de toda comunicação, e irretrocedíveis porque, como veremos, obrigam o emissor da mensagem, em nome da significatividade e da sensatez da interação, a reconhecer imediatamente sua inconsequência na hipótese de pretender negar tais pressupostos e dispensando, portanto, o interlocutor de buscar numa regressão ao infinito a fundamentação última da linguagem. Tais condições universais e irretrocedíveis sustentam, como veremos no pensamento de Apel, a comunicação humana, além de reabrirem, à maneira do criticismo kantiano, a perspectiva de uma razão prática capaz de fundamentar eticamente a linguagem e as ações humanas.

4) A pesquisa linguística de John L. Austin, seguida e aprofundada por John Searle, integra diretamente o itinerário filosófico que conduziu às pragmáticas de Apel e Habermas. Tal pesquisa parte de uma distinção entre sentenças constatativas - aquelas que descrevem coisas ou estado de coisas localizados no mundo natural ou objetivo e que se avaliam como verdadeiras ou falsas - e sentenças performativas (to perform) - aquelas que não descrevem, mas praticam ações no próprio ato de se proferi-las. Um exemplo das primeiras seria o de alguém que dissesse - "As nuvens recobrem o pico das montanhas": nesse caso, descrevese algo fora de quem fala e de quem ouve, sendo que tal tipo de enunciado pode corresponder ou não à realidade das coisas ou estado de coisas que descrevem, sendo, então, passível logicamente de um valor de verdade; as segundas sentenças exemplificar-se-iam por alguém que dissesse - "Prometo que chegarei mais cedo": nesse caso, a sentença, em princípio, não intenciona prioritariamente descrever algum fato nem fazer uma referência ao mundo das coisas, não sendo, portanto, passível de avaliação como verdadeira ou falsa, mas pratica a ação de prometer no próprio ato de fala e cujo empenho comunicativo se dirige à vida intersubjetiva, abrindo caminho para uma percepção ética da linguagem; as sentenças constatativas se referem ao mundo das realidades objetais ou fatuais, enquanto as performativas se referem ao mundo dos sujeitos humanos. Mas, a partir desse ponto da investigação, Austin supera a distinção rígida feita no início da pesquisa e estende a performatividade dos atos de fala a todas as sentenças na medida em que se percebe que os proferimentos constatativos também implicam o empenho implícito ou explícito da palavra de quem fala perante uma presença interlocutiva, como se dissesse - "(Eu afirmo que) as nuvens recobrem o pico das montanhas": afirmar é uma ação tanto quanto prometer e, enquanto tal, implica igualmente o empenho compromissório do dialogante com aquilo que declara frente 


\section{ALCEU}

àquele para quem declara. A partir daí, derivam-se duas consequências para o entendimento dos atos de fala. A primeira é a percepção de que todo ato de fala inclui três dimensões: a dimensão locucionária que se refere "ao aspecto linguístico propriamente dito, isto é, às palavras e sentenças empregadas, dotadas de sentido e referência e de acordo com regras gramaticais" (MARCONDES, 2017, p. 70); a dimensão ilocucionária é a força ativa do ato de fala, aquilo que caracteriza a praticidade constitutiva da linguagem e que instaura expectativas recíprocas na relação entre dialogantes: "Eu prometo que"; a dimensão perlocucionária é aquela que produz, intencionalmente ou não, uma reação na audiência a partir da ilocução proferida: um efeito de obediência, de ameaça, de expectativa, etc. A segunda consequência é o reconhecimento de que todo ato de fala é composto, em si mesmo, caracteristicamente, por uma força ilocucionária, performativa, acionada verbalmente por um locutor em direção a um interlocutor, quer dizer, por um empenho persuasório que prescreve e credita a fala intersubjetivamente: "afirmo", "prometo", "confesso", "condeno", "previno", etc, e por um conteúdo propriamente proposicional de natureza referencial e objetiva que descreve e aponta para o mundo das coisas e dos fatos, respectivamente, "que as nuvens recobrem o pico das montanhas", "que chegarei mais cedo", "que agi traiçoeiramente", "por grave delito", "que revidarei", etc; cada ilocução proferida verbalmente estabelece um tipo de relação prática e dominante com a interlocução, ainda respectivamente em relação aos exemplos dados: "de informação", "de expectativa", "de entrega", "de punição", "de vingança”, etc. Então, não é que os enunciados anteriormente definidos como constatativos percam seu encargo designativo do mundo, mas se distinguem dos atos de fala propriamente performativos porque sua tônica ilocucionária está prioritariamente dirigida para a representação de coisas e situações do mundo objetivo e não para seus envolvimentos intersubjetivos, quer dizer, o compromisso comunitário da fala não se assenta, neste caso, na pretensão de correção ética das normas interativas, mas na pretensão de verdade do enunciado figurativo. Os estudos linguísticos de Austin e Searle avançam, então, no sentido de inscrever a linguagem numa dimensão essencialmente pragmática, desvendando uma razão prática e indo além do positivismo lógico na sua compreensão exclusivamente sintático-semântica e contemplativa da comunicação: toda fala possui uma força ilocucionária que é o empenho e o compromisso do sujeito falante perante uma interlocução humana. E mais do que isso: a partir de Austin e Searle, nas pragmáticas de Apel e Habermas, concebe-se toda comunicação como metalinguagem na 
medida em que sua força ilocucionária modula e reinterpreta o sentido categorial da sentença: o que quer dizer uma mensagem não se esgota na sua pura emissão gramatical.

5) Para superar, então, a tentativa infrutífera de fundamentação filosófica última baseada em prova direta, ou seja, em conclusões lógicas a partir de uma sucessão de premissas tomadas como verdadeiras, Apel, relativamente aos fundamentos éticos da comunicação humana, recorrerá ao método da prova indireta. Ao invés de procurar os fundamentos filosóficos numa cadeia apodítica de sentenças que conduziria o pensamento inevitavelmente a um dos vícios do trilema lógico, vai buscar a certeza sobre os condicionamentos éticos de toda interação linguística consequente, não diretamente na própria sentença proferida pelo locutor, mas indireta e reflexivamente no próprio interlocutor que refuta a sentença que afirma a necessidade daqueles condicionamentos. A sustentação e o reconhecimento últimos da verdade das condições pragmático-transcendentais da linguagem não serão mais buscados na locução monológica de um agente falante que encadeia sentenças a partir de sentenças, mas na interação dialógica, quer dizer, não se localiza mais na tese de um locutor, mas na própria antítese de seu interlocutor cético: as próprias condições que dão sentido à argumentação daquele que refuta a verdade dos pressupostos necessários de sua tese invalidam sua própria refutação. Entenda-se: a suspensão cética dos juízos se aplica aos conteúdos existenciais e contingenciais de uma argumentação, mas não às suas condições pragmático-transcendentais, quer dizer, aos pressupostos necessários e universais que dão sentido aos conteúdos materiais do proferimento, quaisquer que sejam eles. Classicamente, em alguns momentos auspiciosos da história da filosofia, de algum modo se pôs em prática 0 método da prova indireta. Aristóteles, na Metafísica, reconhecendo a impossibilidade de uma demonstração direta do princípio de não-contradição, propôs um tanto desafiadoramente que aquele que o negasse o fizesse a partir de uma argumentação que transgredisse o princípio da não-contradição mas se mantivesse inteligível no próprio transcurso da negação: não é possível dar sentido ao que quer que seja na contradição sistemática consigo mesmo, quer dizer, admitindo-se simultaneamente a validade do que se diz e do contrário do que se diz (ARISTÓTELES, 1994); na autorreflexividade de seu argumento ontológico, Agostinho também se sustenta na prova indireta: "Si fallor, sum", são contraditórias a certeza de que falo e a certeza de que não existo; o "Cogito" cartesiano também pressupõe uma refutação impossível da existência do próprio sujeito a partir de sua dúvida hiperbólica: "eu, que penso, 
não sou”. Em todas as três provas indiretas exemplificadas, há uma autocontradição em seus possíveis refutadores. Na pragmática transcendental de Apel, como veremos, a prova indireta de fundamentação última se amplia e recobre todas as condições que sustentam a ética do discurso, quer dizer, toda fala dotada de sentido e consensualmente consequente.

6) Na sua crítica ao falibilismo radical - aquele que coloca todas, absolutamente todas, as proposições sob permanente falibilidade -, Apel argumenta que o problema deste não é a dúvida em si das hipóteses científicas ou doxológicas que, de resto, devem sim ser submetidas a falseamentos sistemáticos, mas o fato de que o falibilismo não pensa reflexivamente sobre as condições transcendentais de crítica das certezas e de suas próprias críticas. Apel compara a situação do cético falibilista ao paradoxo do mentiroso, inspirado, por sua vez, no clássico paradoxo do cretense Epimênides, quando disse "Todo cretense é mentiroso": o próprio formulador da sentença anula seu argumento porque, como cretense, também incorre na mentira, donde se conclui que a crítica do falibilista às hipóteses levantadas por um falante, analogamente à sentença de Epimênides, não pode atingir as condições de possibilidade a priori e necessárias de sua própria crítica, sob pena de invalidar sua dúvida mesma: o falibilista que disser "Todas as declarações são falíveis" estará autocontradizendo-se e falibilizando sua própria declaração: simplesmente é absurdo e sem sentido que um proponente não invista a priori uma pretensão de validade em quaisquer de suas ofertas sentenciais. O falibilista, a bem da sustentação filosófica de sua crítica, deve, então, se restringir às hipóteses contingenciais do conhecimento e excluir de sua crítica as condições filosóficas ou pragmático-transcendentais que a tornam possível e lhe dão sentido argumentativo. Da mesma forma que a proposição que diz "Só o conhecimento empírico é verdadeiro" não pode ter origem ou ser inspirada na própria empiria, o princípio da falibilidade das hipóteses frasais não pode ele próprio ser falível. Apel quer demonstrar que a sustentação transcendental do conhecimento e da comunicação não se posiciona numa relação simétrica com a contingencialidade falível dos conteúdos proposicionais. Há que se distinguir, de um lado, a falibilidade dos conteúdos sentenciais da metafísica e das ciências experimentais assim como das hipóteses espontâneas do senso comum e, de outro, as condições pragmático-transcendentais, universais e infalsificáveis, que definem a filosofia e que dão sentido a toda argumentação consequente. (APEL, 1991, p. 120) O método de prova indireta da fundamentação última da filosofia está assentado no conceito apeliano e também 
habermasiano de contradição performativa. Tal contradição consiste numa incongruência entre as intranscendíveis intenções ilocucionárias de quem emite uma sentença cética ou qualquer outro tipo de sentença que se pretenda consequente e o próprio conteúdo proposicional declarado na sentença, quer dizer, numa incongruência entre a dimensão performativa e a dimensão constatativa do proferimento: o cético que argumenta a favor de sua tese deve necessariamente, para ter sentido na argumentação, afirmar a pretensão de validade ou de verdade daquilo que está negando no seu conteúdo proposicional e constatativo. A autocontradição em que incorreria o cético na hipótese de negar a validade do que diz demonstra reflexiva e indiretamente a verdade infalsificável das condições que dão sentido à sua e a toda argumentação: aquele que argumenta para afirmar ou negar o que quer que seja deve necessariamente afirmar, explícita ou implicitamente, a pretensão de validade como condição transcendental de seu ato comunicativo. Ninguém argumenta, por exemplo, com a intenção de invalidar a priori o próprio conteúdo da argumentação. A evidência performativa das pressuposições necessárias da linguagem é indireta porque não é baseada na pretensa demonstração direta através de uma cadeia de evidências regressivas ao infinito por parte daquele que declara, isto é, do proponente, mas na reflexividade autocontraditória do cético que nega, isto é, do oponente. Apel quer reconstruir reflexivamente as condições infalíveis e irretrocedíveis de toda comunicação a partir da prova indireta ou da evidência performativa. Em suma, não se procuram as condições transcendentais e fundacionais da comunicação diretamente através de uma sucessão de afirmações direcionada à autoevidência de uma verdade última e inalcançável, mas indiretamente no disparate autocontraditório de sua hipotética negação, quer dizer, as transcendentalidades da linguagem não se as encontram num monólogo autocraticamente conclusivo, mas socraticamente num diálogo com o outro ou consigo mesmo (APEL, 1985).

7) Uma das concepções centrais da pragmática transcendental está no reconhecimento da natureza ao mesmo tempo racional e valorativa de toda ação humana consequente. Por um lado, essa dimensão racional recobre as ações normativas tradicionalmente distinguidas, em sua natureza, das proposições objetivas das ciências naturais. Por outro lado, a própria ciência positiva, para além da objetividade e da universalidade necessárias de seus conhecimentos, está cercada de valores éticos no que tange a seus interesses motivacionais e finalidades culturais. No caso das ciências naturais, há uma diferença entre a objetividade 
de seus conhecimentos e os valores éticos que dão sentido à ciência e à tecnologia como iniciativas culturais, quer dizer, a ciência e seus resultados devem ser justificados quanto a seus fins e motivos históricos tanto quanto as ações que se referem às normas que regem diretamente as relações humanas: "a que interesses históricos estão servindo, por exemplo, concreta e predominantemente o motor a diesel, a energia nuclear ou a comunicação virtual?". Toda ação humana, seja no campo abstrato do pensamento especulativo ou das ciências experimentais e positivas, seja no campo concreto das interações informais do cotidiano, apresenta três dimensões que apontam para um universo valorativo, distinguindo-a no seu conjunto como de natureza deôntica e, portanto, como dever-ser: primeiro, ela se define a partir de uma liberdade de escolha que a diferencia das leis naturais, podendo ser praticada ou não; segundo, ela beneficia ou prejudica direta ou indiretamente as relações intersubjetivas, quer dizer, reforça ou agride os valores e os acordos da convivência sóciohumana e, terceiro, a validade dela, ao contrário das leis naturais, pode ser posta em questão e exigir seu resgate argumentativo, ou seja, um reforço racional na sua pretensão de validade baseada no princípio de universalização. Então, tanto quanto as leis naturais se validam na universalidade objetiva de seus fenômenos, os valores morais se validam na universalidade intersubjetiva de seus interesses, quer dizer, devem se validar, sempre que se exige, numa argumentação racional cujo único sentido possível é demonstrar a superação das inclinações sensíveis, por ventura, lesivas à interação comunitária. A linguagem é ação, é pragma, é simultaneamente performance e proposição, empenho ilocucionário e assertividade, prescrição e descrição, não havendo, portanto, ruptura axiológica entre o móbil objetivante da ciência natural e o móbil das ações diretamente intersubjetivas: todo discurso é ético, toda razão é prática.

8) Deve-se assinalar que para Apel, assim como para Habermas, a ideia de discurso se enquadra numa definição particular de linguagem. Distinguem-se dois patamares da ação comunicativa: a interação e o discurso; a interação ocorre na interlocução espontânea do mundo da vida, onde as ofertas opinativas entre os parceiros linguísticos não estão sob questionamento e a troca flui aproblematicamente; no momento, no entanto, em que uma emissão é contestada na sua pretensão de validade por um dialogante, interrompe-se o fluxo espontâneo e passa-se ao nível do discurso: o falante questionado deve resgatar as razões de sua pretensão numa argumentação que reponha ou não o diálogo na direção do consenso; 
o discurso vige na suspensão crítica dos pressupostos da tradição. A ideia de discurso está vinculada, portanto, à prática da argumentação, quer dizer, à iniciativa de expor racionalmente a pretensão de validade de um juízo opinativo na situação em que os argumentos necessitam, como compromisso diante de um auditório, do reforço persuasório de suas razões. Uma argumentação atualiza-se, enquanto tal, na crise de validade aberta por uma comunidade interlocutiva: o discurso não é, então, uma troca de evidências já consensuadas entre parceiros dialógicos, mas uma disputa crítica entre ponentes e oponentes pelo melhor argumento. Fica também evidenciada a natureza racional da ética na medida em que as opções valorativas do comportamento são também criticáveis e resgatáveis argumentativamente na sua legitimidade comunitária. Nesse sentido, a ideia de discurso em Apel e Habermas é muito mais do que meramente uma prática verbal, mas uma virada que fez a filosofia avançar do paradigma cartesiano-kantiano-husserliano, centrado numa consciência individual, para uma consciência comunitária: toda argumentação pressupõe uma alteridade real ou virtual, além de uma insuficiência para validar qualquer pretensão de verdade a partir de uma subjetividade isolada. $O$ discurso, enquanto momento crítico da linguagem, se distingue também como dimensão ético-política na medida em que, como veremos, deve ser calcado em precondições normativas que garantam o sentido consequente de qualquer locução perante uma interlocução. Tais condições contrafáticas e pressupostas universalmente é que legitimam as normas fáticas dos acordos comunitários. Entenda-se, então, que, ao contrário da linguagem poética cujo predicado essencial é a pura expressão subjetiva do sentido através de imagens e sentimentos, a linguagem argumentativa é constitutivamente a busca de justificação racional e consensuada do sentido; não é, pois, um encontro puramente estético entre subjetividades, mas uma pretensão de validade pública do sentido e, portanto, reconhecida intersubjetivamente.

9) A reviravolta operada pela pragmática transcendental de Apel, em vários aspectos seguidos por Habermas, significa, então, num sentido mais amplo, como já estamos vendo, a transformação filosófica do paradigma da consciência no paradigma da linguagem enfatizada como essencialmente transubjetiva (o giro pragmático). A partir de tal giro linguísticopragmático, a pergunta kantiana sobre as condições de possibilidade do conhecimento passa também por duas mudanças correlatas e radicais: a primeira é que tais condições de conhecimento não serão mais interrogadas e fixadas no interior do "eu penso" fechado e 
solitário, mas na abertura interativa e solidária do "nós argumentamos"; a segunda é que uma tal mudança de território - da apodeixis sintático-semântica para o élenchos pragmáticorefutativo - desloca necessariamente a própria ideia de verdade, a ser sustentada em qualquer situação dialógica, da consciência monológica e dogmática de um sujeito individual para uma razão comunicativa constitutivamente aberta ao diálogo, à intersubjetividade e buscando um consenso, ainda que sempre provisório. Em outras palavras: a pragmática transcendental é a passagem crítica de um intelecto filosófico que legisla monocraticamente sobre o mundo a partir de uma cadeia de verdades axiomáticas e autossuficientes, fora do tempo e do espaço, para um sujeito histórico e comunitário que pensa e repensa, faz e refaz a verdade nos universais do consenso. Além das pesquisas linguísticas de Austin e Searle, três outras iniciativas filosóficas contribuíram para a virada na compreensão predominantemente pragmática da linguagem. O conceito de "jogos de linguagem" do segundo Wittgenstein mostrava o sentido e a compreensão do mundo essencialmente como uso concreto e situacional da comunicação: a linguagem é ação e invenção; não é estrutura, é acontecimento; é acordo local e atual entre interlocutores, dinâmica interativa entre agentes falantes e jamais se esgotando primordialmente na formalidade lógico-sintática dos conceitos ou na semântica pictórica das palavras (adequatio rei ad intellectum); enfim, não se abstrai numa pura intelecção, mas encarna uma pragmaticidade constitutiva: é ação social, é "forma de vida". A hermenêutica de Heidegger, avançada por Gadamer, fez da compreensão não um método de interpretação do mundo, mas uma estrutura constitutiva do próprio Dasein, do ser-aí, do homem herdeiro da tradição, dos valores e das precompreensões que antecipam seu entendimento das coisas: o mundo da vida é preconstitutivo do testemunho individual e, neste, o sentido sempre já começou, nunca inauguramos nossa consciência, nunca estamos no marco zero da linguagem; ao contrário, estamos, desde sempre, mundanamente lançados na existencialidade, trocando e decifrando signos: a alteridade está originariamente instalada na comunicação; a finitude e a imperfeição do humano desautorizam qualquer intelecto onipotente e solipsista a explicar totalizantemente o tempo e a vida; a constitutividade hermenêutica do sujeito é pensada não só como um ser-no-mundo (Dasein), mas correlativamente como um ser-com-os-outros numa comunidade linguística universalmente compartilhada; a verdade não se a encontra num sujeito que nomeia e manipula um objeto, mas na própria linguagem que pastoreia o ser. A semiótica de Peirce, por sua vez, estruturada 


\section{ALCEU}

numa tricotomia que interliga objeto, signo e interpretante, também refaz, na visão de Apel, a questão criticista da possibilidade e da validade da cognição humana na medida em que a representação simbólica das coisas e estado de coisas ocorre, em última instância, na relação interpretativa do sujeito de conhecimento com o mundo. Acontece que essa interpretação se dá necessariamente no interior de uma linguagem que antecede, no seu uso pragmático, o estoque significativo do intérprete individual e é compartilhada intersubjetivamente por sua comunidade linguística; nunca estamos em estado de castidade semântica diante de coisas e situações, mas, pelo contrário, desde sempre, atolados e encharcados de linguagem, hermeneuticamente antecipados e pré-constituídos como intérpretes do mundo; a partir daí, a validade de todo conhecimento, como concebem outros pragmaticistas, extravasa 0 solipsismo de uma consciência solitária, abrindo-se para o consenso numa comunidade de intérpretes; Peirce pensava sua semiótica basicamente voltado para a pesquisa científica e como método de investigação entre parceiros eticamente isentos de interesses particulares ou o que chamou de socialismo lógico, mas Apel estende esse procedimento universalista da ciência peirceana para o entendimento possível entre todos os seres racionais e linguisticamente competentes no confronto comunitário com as questões existenciais e políticas. A pragmática transcendental de Apel reconstrói os conceitos de ilocução em Austin e Searle, de jogos de linguagem em Wittgenstein, de hermenêutica em Heidegger e Gadamer e de semiótica em Peirce no sentido da transformação da filosofia kantiana ao deslocar a questão das condições de possibilidade e validade do conhecimento, classicamente definida na interioridade de um sujeito cartesiano, para uma comunidade ideal de comunicação, quer dizer, uma intersubjetividade que reinterpreta e legitima, a cada vez, a validade da cognição e do consenso. No extremo, a pragmática de Apel reescalona universalmente a competência discursiva do humano e recoloca a validação dos argumentos de volta às discussões populares no ambiente democrático e histórico da praça pública.

10) A natureza transubjetiva da linguagem se define também pelo espaço intermediário que necessariamente ocupa entre os polos extremos e hipotéticos da concordância ou da discordância a priori e incondicional por parte do interlocutor daquele que fala: em nenhum dos dois casos extremos, faria sentido qualquer investimento argumentativo porque, no polo da concordância, um "consenso" absoluto e irracional já estaria desde antes estabelecido; no polo oposto, uma discordância igualmente absoluta e irracional seria impeditiva de qualquer 
acordo. A linguagem humana vive, em princípio, o paradoxo de uma pluralidade desarmônica entre interesses particulares que, não obstante, só podem se satisfazer na relação com a própria alteridade sócio-humana, o que torna toda comunicação desprovida de pretensões consensuais um babelismo inconsequente e sem sentido. Numa releitura amplamente corretiva das interpretações usuais sobre Thomas Hobbes no Leviatã, sua fundação política da humanidade figura, entre outras figurações, como a passagem antropológica da natureza para a cultura, sendo que tal passagem teria ocorrido através de um acordo universal que teria reduzido os interesses individuais instintivos, reciprocamente violentos e exterminadores, a um denominador comum capaz de suspender a selvageria da "guerra de todos contra todos". Esse acordo demonstra a linguisticidade e a complementaridade constitutivas do animal cultural. Ele inaugurou a comunicação, rompeu com o mutismo da selva, artificializou a instintividade e evidenciou que a existência individual do humano é tal que não se basta a si mesma, que sua socialidade é mais do que um arbítrio eventual da espécie, que o denominador comum do acordo político é a garantia da convivência pacífica, a troca compensadora de virtudes, a fruição estética do outro e a realização integrativa do interesse de cada um. Ora, o acordo ocorre na linguagem e a linguagem legítima é, então, inamissivelmente dialógica, motivada por uma pretensão de validade, predisposta à refutação racional e desejosa de consenso.

11) Então, para Apel, como adiantamos, a fundamentação filosófica última infrutiferamente buscada no modelo demonstrativo lógico-formal que não deixa de redundar numa regressão ao infinito ou numa petição de princípio deve ser buscada e demonstrada a partir do conceito de autocontradição performativa, quer dizer, buscada e demonstrada naqueles pressupostos de toda argumentação que nenhum argumentante poderia pôr em dúvida sem refutar-se ou contradizer-se a si mesmo: uma evidência performativa fundamenta irretrocedível ou irregressivelmente os pressupostos de toda argumentação legítima (APEL, 1986, p. 154). Isso quer dizer que todo argumentante deve, coerentemente com o investimento ilocucionário de sua argumentação, reconhecer a existência de uma comunidade real de comunicação constituída por interlocutores potencialmente críticos de seus proferimentos. Tal reconhecimento está radicado na própria natureza hermenêutica e precompreensiva da linguagem que torna necessário o entendimento das referências e dos termos trocados entre os partícipes do jogo argumentativo: para que os argumentos de cada interlocutor na 


\section{ALCEU

comunidade real de comunicação sejam reconhecidos na sua pretensão de validade, visando o consenso, deve haver antecipadamente um acordo semântico que só se realiza na intersubjetividade comunitária dos falantes; estes estão, pois, "condenados 'a priori' ao 'acordo' intersubjetivo". Por outro lado, na medida em que toda comunidade real de comunicação pressupõe necessariamente a busca de um acordo - sem o que perderia todo sentido - pressupõe também e necessariamente uma comunidade ideal de comunicação como antecipação contrafática da comunidade real. A comunidade ideal de argumentação é que orienta e define, na sua idealidade reflexiva, as condições plenas de toda realização de acordos: as condições empíricas de discordância dos interesses privados na comunidade real, reduzidas a si mesmas, não poderiam parametrizar e reencaminhar, a cada vez, as dissemetrias situacionais e históricas impeditivas de um consenso legítimo. Todo argumentante, na situação concreta do diálogo, já pressupõe, sob pena de inconsequência e insensatez, as condições contrafáticas e norteadoras do acordo intersubjetivo. A reflexão das condições transcendentais pressupostas no confronto dialógico e comunitário evidenciam, entre outras, as pretensões de validade universal dos argumentos. A negação de tais condições transcendentais na comunidade real é absurda e performativamente autocontraditória. Isso quer dizer que a comunidade ideal de comunicação não se relaciona com a comunidade real exteriormente como uma abstração puramente idealizada e fora de toda concretude comunicativa, quer dizer, como uma utopia ou modelo dialógico que pudesse ser arbitrariamente ignorado, mas como uma instância, em alguma medida, já sempre e necessariamente em operação e pressuposta pelo sujeito falante para dar possibilidade e sentido à sua troca linguística na busca de consenso: ninguém, por exemplo, poderia pretender argumentar seriamente mostrando a priori intolerância com a disposição crítica do interlocutor; "o curioso e dialético da situação consiste em que quem argumenta pressupõe, de certo modo, a comunidade ideal 'na' real, como possibilidade real da sociedade real, ainda que saiba que a comunidade real - incluindo ele mesmo - está muito longe de identificar-se com a ideal'(APEL, 1985, p. 407-8): o reconhecimento de uma alteridade potencialmente crítica é condição insuperável de toda comunicação significante. A utopia pragmáticotranscendental não é, pois, um não-lugar vigendo numa pura idealidade filosófica, quer dizer, numa virtualidade política acima do mundo concreto, mas uma possibilidade histórica, em alguma medida, sempre já em prática na vida humana, ainda que perenemente em vias de 


\section{ALCEU}

atualização. É nesta vigência da reciprocidade dialógica, ainda que parcial e às vezes até diminuta, que se abre historicamente a possibilidade do discurso crítico e alternativo.

12) Apel aprofunda, então, a reflexão sobre as condições pragmático-transcendentais de todo discurso - aquelas condições que não podem ser negadas sem que o argumentante incorra em autocontradição performativa. Tais pressuposições se materializam, como já sugerimos, enquanto pretensões de validade que motivam necessariamente todo falante em qualquer declaração consequente e se distinguem em pretensões de inteligibilidade, de verdade, de retitude e de sinceridade. A pretensão de inteligibilidade, por exemplo, se, por ventura, negada pelo falante, coloca-o imediatamente em desencontro performativo consigo mesmo na medida em que, na hipótese de dialogar seriamente e ser questionado, deve argumentar compreensivelmente pela validade de sua negação e, na recusa em fazê-lo, estaria desqualificado para continuar na comunidade comunicativa: o emissor de qualquer mensagem não pode renunciar às regras de significação da linguagem pública porque, no contexto interlocutivo e na exigência de resgate de suas razões, teria que deixar isso inteligivelmente claro; o mesmo ou outro qualquer falante também não poderia se demitir da pretensão de verdade no que predica coisas ou enuncia estado de coisas porque seu ato de fala ilocuciona positivamente, o que contradiria seu próprio conteúdo proposicional: ninguém diria com intenções consequentes que não há nenhuma chance de correspondência entre seu enunciado e a realidade da coisa ou estado de coisas que se dispõe a descrever, quer dizer, seu ato de fala não teria nenhum comprometimento com a chegada possível a um acordo intersubjetivo; da mesma forma, a pretensão de sinceridade, uma vez negada, também poria o emissor em contradição ilocucionária com sua própria referência sentencial: questionado por um interlocutor sobre a sinceridade de seu enunciado, não poderia admitir sua insinceridade sem esbarrar no conteúdo de sua declaração como alguém que dissesse "neste momento, eu minto sobre o que declaro"; finalmente, a pretensão de retitude se refere à adesão implícita do argumentante não só às outras normas de validação que devem conduzir a busca do consenso na interação dialógica dos falantes como ao princípio de isonomia ou igualdade de direitos entre todos os participantes da comunidade linguística e extensível às normas convivenciais de toda a sociedade: qualquer desconsideração quanto às condições isonômicas da interação lesiona e compromete a validade do consenso. 
13) Um dos primeiros passos dados por Apel para a sistematização e consolidação conceituais de uma ética do discurso ocorre, como já vimos, com a transformação semiótica da filosofia que consiste em extrapolar a ética peirceana de uma comunidade de investigadores - que devem restringir ou abstrair seus interesses particulares em nome de um dever de submissão à verdade experimental e científica (selfsurrender) - para o âmbito mais amplo das interações humanas em geral, recobrindo todos os seres pensantes e linguisticamente competentes, quer dizer, reescalonando a ética da comunidade especializada de investigadores para a comunidade ilimitada de comunicação. Ao ressituar a verdade científica na dimensão interpretante da cognição humana, Peirce, então, já houvera aberto o caminho para um entendimento ético-linguístico da verdade, ficando, no entanto, restrito aos métodos objetivantes da pesquisa científica e ao círculo da comunidade de investigadores. Será através de Kant com o princípio de universalização $(U)$ das ações humanas (imperativo categórico) que Apel definirá as condições deontológicas de todo círculo argumentativo em busca de acordo e superação dos conflitos. Em suma, a transformação apeliana da filosofia deslocará, com Peirce, a verdade do plano puramente sintático-semântico-referencial para o âmbito pragmático-interpretativo da linguagem e, com Kant, deslocará o princípio ético universal de uma subjetividade cartesiana herdada pelo criticismo para toda intersubjetividade discursiva em busca de consenso.

14) A ética do discurso deve, portanto, ser definida por um princípio moral fundamental que, por sua vez, implica pressuposições sem as quais a natureza da comunidade ideal de comunicação perderia todo sentido consensualista. A primeira e mais abrangente de suas normas está, então, no princípio de simetria entre os argumentantes da comunidade: todos os participantes da comunidade discursiva devem gozar da igualdade de direitos de livre intervenção no diálogo assim como devem obrigar-se isonomicamente à argumentação racional em favor de suas pretensões de validade e isegoricamente reivindicarem ser ouvidos pelos demais participantes; todo não-reconhecimento interno e arbitrário ou qualquer coação exterior à liberdade de expressão dos argumentantes é desqualificadora do entendimento comunitário. A isonomia entre os participantes do diálogo é o princípio que garante a busca e a chegada possível a um acordo que contempla os interesses coletivos da comunidade real de comunicação. Outro princípio praxeológico e transcendental do discurso é a reciprocidade generalizada que implica o comprometimento e a corresponsabilidade pelas consequências 
das normas acordadas que devem ser aceitas por todos os argumentantes presentes e virtuais da interação comunitária; a consideração kantiana dos sujeitos como fins em si mesmos e jamais tomados estrategicamente num parasitismo da linguagem; a obrigação de resgatar racionalmente os argumentos validadores de suas pretensões sempre que exigido assim como exigir que os outros também o façam, além de reconhecer autocriticamente os melhores argumentos no confronto dialógico. O princípio de universalização (U) da ética do discurso também não admite a limitação das discussões e das decisões ao âmbito especializado dos experts ou dos interesses puramente científicos: todas as ações humanas têm uma motivação valorativa e, portanto, devem buscar uma legitimidade discursiva de amplitude ecumênica; toda fala do ser racional e dotado de competência linguística deve ser reconhecida e legitimada na verbalização intersubjetiva de seus interesses. Vale relembrar e ressaltar que, já sob inspiração da ética científica de Peirce, a pragmática transcendental de Apel não concebe a ética do discurso como apenas mais um complexo de normas que se justaponha simetricamente a outros tantos possíveis complexos regulativos que possam caracterizar a vida intersubjetiva, mas é aquela estrutura na qual e pela qual se exercem, no fático e no contrafático, no real e no ideal, todas as regras de socialidade constitutivas do humano: ações e reações do animal cultural transcorrem exaustivamente na interpretação de sinais e na escolha de valores.

15) A fundamentação filosófica do princípio moral presente em toda comunidade argumentativa é, então, formalizada por Apel através de uma reflexão transcendental acerca das condições de possibilidade e validade de toda argumentação, ou seja, da reconstrução regressiva das normas validadoras de toda discussão, na negação das quais o argumentante entraria necessariamente em autocontradição performativa na própria medida em que teria, uma vez exigido e sob pena de se desqualificar como dialogante, que justificar sua posição, recuperando, assim, circularmente, no mesmo ato de resgate de suas razões, as condições universais e irrecusáveis de sua pretensão de validade. A reflexão transcendental consiste, então, em reconstruir e reconhecer aquelas condições discursivas que não podem ser fundamentadas por nenhum princípio anterior a elas porque elas próprias são já as pressuposições irretrocedíveis e sine qua non de toda prática argumentativa dotada de sentido (APEL, 1985): nenhum conteúdo proposicional, como já vimos, pode entrar em confronto com o empenho performativo de sua pretensão de validade a ser avaliada pelo 
conjunto interlocutivo e só ganhando sentido a partir das condições normativas e irregressíveis da comunidade de argumentação. Tal como para Kant há um factum de razão, para Apel há um factum de argumentação que, por sua própria natureza pragmática como ato de fala, implica uma razão prática, quer dizer, uma racionalidade eminentemente comunicativa cujo caráter ético se evidencia por sua condição de dever-ser, de um a fazer e não de puro ser já dado e acabado: tomando como referência o mundo objetivo de coisas e estado de coisas ou o mundo intersubjetivo das ações morais, todo ato de fala exige uma legitimação consensual cujas normas éticas e condições de sentido, por sua própria natureza imperativa, podem não ser cumpridas por um dialogante. Por outro lado, embora na dependência da decisão individual de se cumprir ou não as condições éticas do discurso, sua violação é o comprometimento fatal do consenso e a perda de sentido da linguagem argumentativa: 0 compromisso com a busca tendencial do consenso é o que distingue a fala discursiva da parola que atematiza valores e costumes; como decisão livre, a aceitação ou rejeição do dever-ser ético do discurso por parte do dialogante significa estar ou não estar na situação comunicativa legítima e, portanto, estar ou não estar na civilização ou na barbárie. Então, a linguagem se abre em duas dimensões: a linguagem-objeto que fala sobre o mundo, mas não fala sobre si mesma, aquela da ciência e do senso comum sempre falível e revisável; e a linguagem reflexiva, propriamente filosófica, que fala sobre si mesma e reconstrói os pressupostos normativos e inegociáveis de toda comunicação com sentido. As condições éticas pressupostas como possibilidade de toda argumentação não são, pois, convenções empiricamente consensuadas como o são as normas estipuláveis e corrigíveis a partir das trocas dialógicas dentro de uma comunidade real de comunicação na busca de consenso, mas normas sempre dadas a priori e já contrafaticamente antecipadas por todo aquele que entrar no jogo transcendental do diálogo e se propuser eticamente a uma formação racional e comunitária da vontade: os pressupostos intranscendíveis da linguagem, explícita ou implicitamente admitido por todo falante, sob pena de autocontradição performativa, não se buscam, pois, no lá-então de um princípio primeiro sintonizado especulativamente, mas no aqui-agora dos pressupostos de todo ato de fala ou agir comunicativo.

16) Reconhecendo a vigência necessária, mas parcial da ética do discurso na história corrente da vida humana, Apel se vale da distinção weberiana entre ética da convicção e ética da responsabilidade para construir sua "arquitetônica" filosófica em duas partes: A e B. Na parte 


\section{ALCEU}

A, ele identifica as normas éticas fundamentais da comunidade ideal de comunicação com a ética da convicção cujos valores não se dobram, em princípio, a nenhuma situação concreta das contingencialidades humanas e, na parte $\mathrm{B}$, identifica exatamente as condições materiais em que se situa a comunidade real de comunicação e que exigem uma ética da responsabilidade a ser aplicada em contextos estratégicos que devem flexibilizar a realização de valores. Em outras palavras: há uma abstração nas condições contrafáticas necessariamente pressupostas na comunidade ideal de comunicação que devem orientar a comunidade real, mas não respondem imediatamente às necessidades concretas em que se realizam e se cumprem acordos, em virtude da diversidade conflituosa dos interesses humanos em jogo e das incertezas advindas dos chamados sistemas de autoafirmação como indivíduos, famílias, grupos sociais ou o próprio estado cujo compromisso com os interesses universais do acordo original podem se tornar problemáticos, especialmente nas situações políticas. A ética fundamental do discurso desconsidera, por sua natureza ideal e abstrata, a situação particular da moral de determinados indivíduos ou a responsabilidade pelas consequências práticas de suas decisões: impõe-se uma mediação estratégica do princípio moral. Uma desconsideração da ética da responsabilidade na administração dos acordos redundaria para Apel num rigorismo da convicção moral à maneira do imperativo categórico kantiano e que seria incapaz de dar conta das situações estratégicas onde efetivamente se passam as ações históricas do humano. As duas éticas - a da convicção e a da responsabilidade - são inspiradas em Weber, mas Apel faz delas não apenas um reconhecimento necessário da realidade sócio-humana, mas também uma utopia concreta onde o real comunitário pode e deve se aproximar tendencialmente de um ideal cosmopolita e discursivo. É a partir desta aproximação que Apel idealiza estrategicamente, com a ajuda do instrumental da Psicanálise e da crítica das ideologias, uma autorreflexão progressiva e uma práxis emancipatória do gênero humano.

17) Finalmente, o que fique talvez de mais significativo da pragmática transcendental de Apel, como se verá também na pragmática formal-universal de Habermas, não seja apenas a superação filosófica de uma subjetividade solitária por uma intersubjetividade mediada linguisticamente ou até mesmo pelo destaque de uma autoconsciência reflexiva do humano, mas o reconhecimento da finitude do sujeito na sua incapacidade de inteligir um absoluto encerrado no tempo e abstraído do espaço; o reconhecimento do sujeito racional como uma 
unidade fragmentar que só forja o sentido de sua existência na interação comunitária; o reconhecimento de uma imperfeição que, sem se deixar cair num relativismo babélico ou na algaravia desordenada de infinitas vozes, tenha como sina e como tormento, sempre que se comunica, almejar uma verdade que avança e recua, se aproxima e se afasta, torturantemente: a linguagem é o suplício de Tântalo.

Drauzio Gonzaga Professor do Departamento de Comunicação da PUC-Rio Doutor em Filosofia, UFRJ

Recebido em: 18 de março de 2019

Aprovado em: 08 de abril de 2019

\section{Referências}

ALBERT, Hans. Tratado da razão crítica. Rio de Janeiro: Tempo Brasileiro, 1976.

APEL, Karl-Otto. Éthique de la discussion. Paris: Les Éditions Du Cerf, 1994.

. La transformación de la filosofia: I, II. Madrid: Taurus, 1985.

Discussion et responsabilité (L’étique après Kant). Paris: Les Éditions Du Cerf, 1996.

Estúdios éticos. Barcelona: Alfa, 1986.

Teoria de la verdad y ética del discurso. Barcelona: Paidós, 1991.

Estudos de moral moderna. Petrópolis: Editora Vozes, 1994.

ARISTÓTELES. Metafísica, 1006a. Madrid: Gredos, 1994.

CENCI, Angelo Vitório. A Controvérsia entre Habermas e Apel acerca da relação entre moral e razão prática na Ética do Discurso. Campinas: Biblioteca Unicamp, 2006.

CORTINA, Adela. Razón comunicativa y responsabilidad solidaria. Salamanca: Sigueme, 1988.

MARCONDES, Danilo. As armadilhas da linguagem (significado e ação para além do discurso). Rio de Janeiro: Zahar, 2017. 
OLIVEIRA, Manfredo Araújo. Reviravolta linguístico-pragmática na filosofia contemporânea. São Paulo: Loyola, 1996.

\title{
Resumo
}

O texto pretende apresentar, na forma de tópicos coordenados, a primeira parte da "arquitetônica" filosófica de Karl-Otto Apel em que ele define os princípios fundamentais de uma ética do discurso como condições contrafáticas significativamente presentes e pressupostas em toda comunidade ideal de comunicação. A reflexão transcendental de Apel programa operar uma transformação na filosofia clássica e moderna, deslocando a verdade elaborada por uma consciência solitária e subjetiva que encadeia logicamente sentenças a partir de sentenças, para a construção de consensos entre sujeitos pragmaticamente interativos e conforme condições a priori cuja negação colocaria os interlocutores inevitavelmente em autocontradição performativa. Estes tópicos não se referem à segunda parte da "arquitetônica" de Apel que trata dos problemas da aplicação da ética da responsabilidade na comunidade real de comunicação, segundo uma perspectiva estratégicoteleológica.

Palavras-chave: Comunidade. Pragmática. Transcendental. Ética. Argumento. Intersubjetividade.

\begin{abstract}
The text intends to present, in the form of coordinated topics, the first part of Karl-Otto Apel's philosophical "architectural" in which he defines the fundamental principles of an ethics of discourse as significantly present and presupposed condition of ideas in every communication community. Apel's transcendental reflection operates a transformation of classical and modern philosophy shifting the idea of truth elaborated by a solitary and subjective consciousness that logically chains sentences from sentences to the construction of consensus between pragmatically interactive subjects and according to a priori conditions whose negation would inevitably place the interlocutors in performative self-contradiction. These topics do not refer to the second part of Apel's "architectural" that deals which the problems of the application of ethics of responsibility in the real community of communication, from a strategic-teleological perspective.
\end{abstract}

Keywords: Community. Pragmatic. Transcendental. Ethics. Argument. Intersubjectivity 